\title{
EFFECT OF GLYCYRRHIZIN ON HEPATIC LYSOSOMAL SYSTEMS
}

\author{
Kazuo NAKAGAWA and Masukichiro ASAMI \\ Department of Fond Science, Kyoto Women's University. Higashiyama-ku, Kyoto 605, Japan
}

Accepted June 7, 1981

Glycyrrhizin (glycyrrhizic acid, $\beta, \beta-$ glucuronido-glucuronide of 18, -glycyrrhetinic acid), occurring naturaliy in the root of glycyrthiza glabra L., has been used either as a medicament for its desoxycorticosteronelike (1) and cortisol-like (2) offects or as a food additive for its sweetness. Glycyrrhizin. which is classified as a saponin, has a protective effect against hemolysis induced by other saponins or a cationic surfactant (3). though saponins are generally characterized by hemolytic action. Thus, it is probable that glycyrrhizin induces alteration in membrano fluidity by reacting with the components of membrane or intercalating its moiety into the mombrane structure.

In this report, we tested biological actions of glycyrhizin on lysosomes, chosen as a tentalive membrane system, by 1) examining whether or not glycyrrhizin affects the hepatic lysosomal enzyme activity itself. and 2) measuring its in vitro release of lysosomal enzymes from tho lysosome granules.

Glycyrrhizin was purchased from Nakarai Chemicals, LTD., and $18 \alpha$ - or 18,-glycyrrhetinic acid was obtained from Sigma Chemical Company. These compounds were used after dissolution in 5 , of dimethylsulfoxide.

Hepatic lysosomes were prepared from male mice (ddY strain, 25-30 g of body weight) by centrifugation at $13,000 \times \mathrm{g}$ for $10 \mathrm{~min}$, according to the method of Wang et al. (4). When we determined direct effects of a test compound on the enzyme activity, we prepared crudo onzyme samples by dissolving lysosomal particles $(13,000 \times g$ pellet) with $0.1 \%$ Triton $X-100$.

Lysosomal enzyme activities were measured by the procedures described by Barret and Heath $(5,6)$. Acid phosphatase (APh) activity was measured by incubating $0.3 \mathrm{ml}$ of enzyme sample with $1.2 \mathrm{ml}$ of $0.2 \mathrm{M}$ acctate buffer $(\mathrm{pH} 5.0)$ and $0.5 \mathrm{ml}$ of $32 \mathrm{mM} 4$-nitrophenylphosphate for $20 \mathrm{~min}$ at $37^{\circ} \mathrm{C}$, and successively adding $2.0 \mathrm{ml}$ of ice-cold $1 \mathrm{M}$ Tris-0.4 M phosphate buffer $(\mathrm{pH} 8.5)$ to terminate the reaction. The assay of $\beta-N$-acetylglucosaminidase (NAcG) activity was carried out under the following conditions. The incubation mixture contained $0.5 \mathrm{ml}$ of enzyme sample. $0.5 \mathrm{ml}$ of $0.3 \mathrm{M}$ citrate-0.3 M NaCl buffer ( $\mathrm{pH} 4.3$ ), and $0.5 \mathrm{ml}$ of $15 \mathrm{mM} 4$-nitrophenyl- $\beta$ - $\mathrm{N}$-acetylglucosaminide. Aftor incubation for $20 \mathrm{~min}$ at $37^{\circ} \mathrm{C}$, the reaction was stopped by adding $1.5 \mathrm{ml}$ of $0.5 \mathrm{M}$ bicarbonate buffer ( $\mathrm{pH} 10.0$ ). In either case. the presence of the liberated 4-nitrophonol was determined spectrophotometrically at $420 \mathrm{~nm}$.

Integrity of lysosome membrane was ascertaincd by moasuring the release of Iysosomal marker enzymes. The release of lysosomal enzymes was induced by incubating for $15 \mathrm{~min}$ at $37^{\circ} \mathrm{C} 1.5 \mathrm{ml}$ of lysosome suspension containing $10 \mathrm{mM}$ Tris- $\mathrm{HCl}$ (pH 7.1) in 0.44 M sucrose-0.177 M $\mathrm{KCl}$ with a test compound in the presence or absence of $0.1 \%$ Triton $X-100$ in the final volume of $2.0 \mathrm{ml}$. In control experiments, the test compound was replaced by a vehicle. After cooling in ice-water. lysosomes were 
centrifugod at $13,000 \times \mathrm{g}$ for $10 \mathrm{~min}$. A portion of the supernatant was removed for the assay of enzyme activity. We regarded the enzyme activity in the supernatant of the sample treated with Triton $X-100$ as total recovered activity because sedimentary cnzyme activity was negligible. Therefore, alteration in total recovered activity may reflect changes in activity of the enzyme itself.

Table 1 shows the effect of glycyrrhizin and its constituents on the activity of lysosomal enzymes which were prepared by solubilizing Iysosome fraction with $0.1 \%$ Triton $X-100$. Both glycyrrhizin and $18 \hat{\beta}$-glycyrnetinic acid. the aglycone of glycyrhizin, attenuated APh activity significantly, but $18 \alpha$-glycyrrhetinic acid and glucuronic acid showed no effects. On the other hand. NACG activity remained unchanged when adding of any the compounds listed above, in a dose of $3 \times 10^{-4} \mathrm{M}$.

Figure 1 shows that the release of APh was enhanced by the addition of glycyrrhizin or $18 \beta$-glycyrhetinic acid, but was reduced by $18 \alpha$-glycyrhetinic acid. Such was evident when the magnitude of the enzyme release was assessed by calculating the ratio of the enzyme activity in the supernatant without Triton $X-100$ (shaded area) to total recovered activity. On the other hand, a remarkable release of NAcG was seen with $18 \beta-$ glycyrrhetinic acid. However, glycyrrhizin induced conflicting effects, that is, an increase at $3 \times 10^{-4} \mathrm{M}$ and a decrease at $10^{-3} \mathrm{M}$.

It has been reported that glycyrrhizin is hydrolized to glucuronate and glycyrrhetinic acid at a low concentration by $\beta$-glucuronidase, a lysosomal enzyme, but inhibits $\beta$ glucuronidase activity non-competitively at a high concentration (7). In addition, we have found that glucuronate had no effect on the lysosomal release of these enzymes (data are not shown). Accordingly, it is probable that the increased release of enzyme in the presence of a low concentration of glycyrrhizin may be due to 18,3 -aglycone as a result of the hydrolysis of glycyrrhizin. while the split of the saponin may be negligible at $10^{-3} \mathrm{M}$. Segal and Milo-Goldzweig (8) reported that aldonolactones, which are specific glucosidase inhibitors, inhibited saponin-induced hemolysis, but showed no protective effect on the hemolysis induced by the sapogenins. The action of glycyrrhizin on the release of $\mathrm{NACG}$ in our report resembles their findings in that a glycoside may stabilize the membrane, while its aglycone may not do so.

The present results indicate that the configuration of $18-\mathrm{H}$ of glycyrrhetinic acid

Table 1. Effect of glycyrhizin and its constituents on lysosomal enzyme activity

\begin{tabular}{|c|c|c|}
\hline \multirow{2}{*}{$\begin{array}{l}\text { Compounds } \\
\left(3 \times 10^{-4} \mathrm{M}\right)\end{array}$} & \multicolumn{2}{|c|}{$\begin{array}{c}\text { Enzyme Activity } \\
\text { (nmoles/mg prot. } / \text { min }) \pm S . E . M .\end{array}$} \\
\hline & $\mathrm{APh}$ & $N A \overline{A C G}$ \\
\hline Control & $54 \pm 1.9$ & $52 \pm 1.2$ \\
\hline Glycyrrhizin & $31 \pm 1.0^{2}$ & $52 \pm 1.2$ \\
\hline $8 x$-Glycyrhetinic acid & $53 \pm 5.9$ & $60 \pm 2.8$ \\
\hline $18 \beta$-Glycymbetinic acid & $49 \pm 1.3^{11}$ & $48 \pm 2.4$ \\
\hline Glucuronic acid & $57 \pm 1.8$ & $52 \pm 1.2$ \\
\hline
\end{tabular}

Crude acid phosphatase (APIr) and $\beta-N$-acetylglucosaminidaso (NAcG) were prepared by dissolving the lysosomal fraction $(13,000 \times g$ petlet) with $0.1 \%$ Triton $X-100$. Each figure represents the mear \pm S.E.M. of four separate experiments. Significance: $a, p<0.001 ; b$, $p<0.01$ 

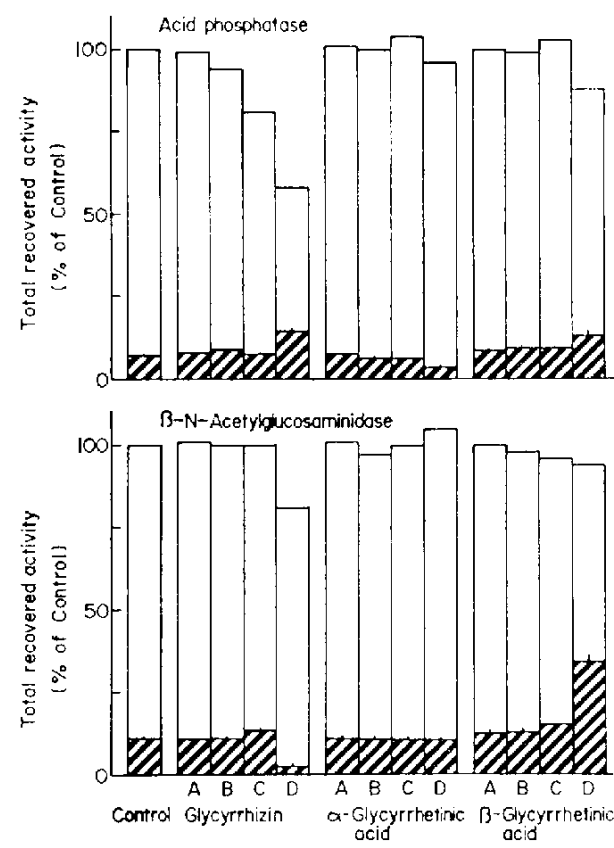

Fig. 1. Each bar represents total recovered activity which appeared in the supernatant after incubating lysosomal particlos with the drug in the presence of $0.1 \%$ Triton $X-100$ and centrifuging as described in the text. Tho total reccvered activity is a percentage of the control. The shaded aroa indicates the onzymo activity which appeared in the supernatant after incubating lysosomal particles with the diug in the absence of $0.1 \%$ Triton $X-100$ and centrifuging (free activity). The magnitude of free activity was represented as a percertage of total recovered activity of control. The mean \pm S.E.M. of 3 to 4 separate experimonts is shown. Drug concentration: A, $10^{5} \mathrm{M}$ : B. $10^{-4} \mathrm{M}: \mathrm{C}, 3 \times 10^{-4} \mathrm{M}: \mathrm{D}, 10^{-3} \mathrm{M}$.

plays an important role in the interaction with components of membrane. Furthermore, the hydrophilic moiety of glucuronate can modify the affinity of the aglycone for lipid layer of membrane by conferring an amphipathic property, and thereby producing alteration in structure and/or fluidity of the membrane. It is also likely that modes of existence of enzymes within lysosomes restrict the action of these drugs because $\mathrm{APh}$ and NAcG gave different responses to the same drug.

Acknowledgements: We thank Prof. K. Kuriyama, Kyoto Prefectural University of Medicine, for pertinent advice. This research was supported in part by research grant (No. 477297. 1979) for Scientific Research from the Ministry of Education, Science and Culture, Japan.

\section{REFERENCES}

1) Morhuysen, J.A., Gerbrandy, J., De Vries, L.A. and De Tong, J.C.: A licorice extract with deoxycortone-like action. Lancet 259, 381$386(1950)$

2) Kumagai, A., Yano, S., Otomo, M. and Takeuchi, K.: The corticoid-like action of glycyrrhizin and the mochanism of its action. Endcr. Japan. 4. 17-27 (1957)

3) Segal, R., Milo-Goldzweig, I., Kaplan, G. and Weisenberg, E.: The protective action of glycyrthizin against saponin toxicity. Biochem. Pharmacol. 26, 643-645 (1977)

4) Wang, C.-C., Straight, S. and Hill, D.L.: Dostabilization of mouse liver lysosomes by vitamin A compounds and analogues. Biochem. Pharmacol. 25, 471-475 (1976)

5) Barret, A.J. and Heath, M.F.: Lysosomes. A Laboratory Handbook. 2nd ed. Edited by Dingle, J.T., p. 113, Elscvior/North-Holland Biomedical Press. Amsterdam (1977)

6) Barret, A.J. and Heath, M.F.: Lysosomes, A Laboratory Handbook. 2nd od., Edited by Dingle. J.T. p. 118-120. Elsevier/NorthHolland Biomedical Press, Amsterdam (1977)

7) Nakao, T.: Glycyrrhizin and $\hat{\beta}$-glucuronidase. Nisshin Igaku 45, 463-468 (1958) (in Japanese)

8) Segal, R. and Milo-Goldzweig, I.: On the mechanism of saponin hemolysis--II. Inhibition of hemolysis by aldonolactones. Biochem. Pharmacol. 24, 77-81 (1975) 